\title{
Job Design and Innovative Work Behavior: One Size Does Not Fit All Types of Employees
}

\author{
Stan De Spiegelaere*, Guy Van Gyes**, \\ Geert Van Hootegem***
}

\begin{abstract}
As innovative employees become imperative for an organizations' success, research identified job design as a crucial variable in promoting innovative work behavior (IWB) (Hammond et al., 2011). Using the Job Demands-Resources (JD-R) model of Bakker \& Demerouti (2007), this article contributes to the literature as it uses recent insights on the distinction between job challenges and job hindrances (Van den Broeck et al., 2010) and distinguishes between blue-and white-collar employees. Using survey data of 893 employees of various organizations the findings generally confirm the JD-R model, although important differences were found between blue-collar and white-collar employees regarding the relation of organizing and routine tasks with IWB. Job content insecurity further was found to be very detrimental for blue-collar IWB. These findings have important HR and political implications as they show that there is no 'one size fits all' $H R$ solution for innovation.

Keywords: Innovative Work Behavior, Job Design, HRM, white collar workers, blue collar workers.
\end{abstract}

\section{Introduction}

As innovation is a central concern for organizations, managers are faced with the challenge of mobilizing the innovative potential of all sorts of employees. As these employees have a capital of tacit knowledge (Polanyi, 1966) about the production process, the work organization and the product design, mobilizing this knowledge can result in workplace innovations with high returns on investments (Getz \& Robinson, 2003). HR managers therefore face the challenge of creating a work environment in which employees can develop and exploit their innovative potential. According to a recent meta-analysis (Hammond et al., 2011), job characteristics are of central importance for employee innovativeness. Beer et al. (1984) identified already in the 80 s job design as a main challenge of HR managers. Recent research on so-called

\footnotetext{
* Ph.d. Student, HIVA-KULeuven, Stan.Despiegelaere@kuleuven.be.

** Research Leader, HIVA-KULeuven, guy.vangyes@kuleuven.be.

*** Prof., CESO-KULeuven, geert.vanhootegem@soc.kuleuven.be.
} 
High Performance Work Systems (HPWS) continued the academic attention on how HR systems can result in positive organizational outcomes. One of the predicted outcomes of the introduction of HPWS is an organization that flexibly responds to new environments. Lorenz \& Valeyre (2005) characterized this model as an organization with high levels of employee autonomy, task complexity, learning and problem-solving. Assumingly, such 'learning type' organizations stimulate and enable their employees to be innovative and flexible. These findings on the meso-level are in line with models and findings on the micro level on the link between job design and employee outcomes (see: Bakker \& Demerouti, 2007; Karasek \& Theorell, 1990). Yet, this individual level literature on the relation between job design and employee innovativeness is nevertheless imperfect. First, the complexity of the relation between job characteristics and employee outcomes is rarely taken fully into account. Although theoretical models like the Job Demands-Resources model of Bakker \& Demerouti (2007) stress the need to focus on the interaction effects between various job characteristics, this is rarely put into practice (Holman et al., 2011; Martín, Salanova, \& Maria Peiro, 2007). Second, various studies have established the fact that HR practices like reward policies (Baer, Oldham, \& Cummings, 2003; Dewett, 2004) have different effects on employees, depending on their personal and group characteristics. Yet, only a few articles took these considerations into account when studying the relation between job design and employee innovativeness (Schreurs, Van Emmerik, De Cuyper, Notelaers, \& De Witte, 2011; Toppinen-Tanner, Kalimo, \& Mutanen, 2002; Tsaur, Yen, \& Yang, 2010). Yet, the HR reality is that jobs are rarely designed in the same way for all kinds of employees in a company. Depending on the level of education of employees, depending on their place in the company and their employment status, HR strategies are designed accordingly.

In the context of the upcoming trend towards more evidence based HRM (Briner \& Rousseau, 2011), this article focuses on finding evidence on how HR practices can be tailored and result in optimal innovative work behavior. The article is the first to link job design to innovative behavior using the recent insights on the double nature of job demands, namely as job challenges and job hindrances (Podsakoff, LePine, \& LePine, 2007; Van den Broeck et al., 2010). Further, the article distinguishes between blue- and white-collar employees in the study of the job design-IWB relation and studies how different job design variables are differently related to IWB.

To develop a series of hypotheses, the article first discusses briefly the concept of innovative work behavior and the relation with job design. Next, the article continues with a discussion on the importance of distinguishing between employee categories in this type of study. Further, the method and the results of the research are discussed. In the last sections we discuss the results and the limitations of the study and draw conclusions. 


\section{Innovative work behavior \& job design: an HR challenge}

Innovation is not only stemming from R\&D efforts. Employees confronted daily with the production process are essential in identifying problems, creating solutions and actually implementing innovations in the workplace. The concept of 'innovative work behavior' tries to capture this workplace reality and can be defined as follows:

"Innovative work behavior is all employee behavior directed at the generation, introduction and/or application (within a role, group or organization) of ideas, processes, products or procedures, new to the relevant unit of adoption that supposedly significantly benefit the relevant unit of adoption"

IWB thus differs from concepts like employee creativity as it not only focuses on the generation of ideas, but also includes behavior related to problem recognition, idea championing and idea implementation (de Jong \& Den Hartog, 2010). It thus encompasses all types of behavior of employees that is related to business innovation at the workplace. Both active support for innovations in the workplace and selfinitiated innovation processes are included in the concept.

Optimally utilizing the innovative potential of employees is a major HR challenge in organizations. Employees are in a unique position to contribute to the innovative character of the organization as they possess a capital of tacit knowledge about the production process, the product and the work organization. Mobilizing this knowledge and enabling the development of workplace innovations is considered the optimal use of the human capital of an organization (Darroch, 2005).

Consequently, this article focuses on the relation between job design and IWB. In doing so, we go beyond the mere study of linear relations between job design variables and IWB, but use the Job Demands Resources model as a point of departure (Bakker \& Demerouti, 2007; Bakker, van Veldhoven, \& Xanthopoulou, 2010). Building on the earlier work of Karasek and Theorell (1990), the JDR model proposes to categorize job characteristics in essentially two groups: job resources and job demands. Job resources refer to the aspects of the work that are functional in achieving the work goals, that can reduce job demand and the associated costs in terms of health and motivation and that stimulate learning and development of employees (Bakker \& Demerouti, 2007). Job demands on the other hand refer to the aspects of the job that require sustained physical or psychological effort or skills. They are associated with costs in terms of health and motivation of employees (Bakker \& Demerouti, 2007). Nevertheless, recent studies found indications for the existence of two distinct types of job demands, namely job challenges and job hindrances (Podsakoff et al., 2007; Van den Broeck et al., 2010). Job hindrances would refer to those job demands that have only negative outcomes in terms of health and motivation. Job challenges on the other hand refer to those job demands that have more mixed outcomes. They would negatively affect health outcomes while at the same time positively affect employee engagement and motivation. Examples of job resources are autonomy, learning opportunities, support of colleagues or supervisors and rewards. Examples of job hindrances are job 
insecurity, role ambiguity and interpersonal conflicts while time pressure and workload are generally seen as job challenges.

In the context of this research we approached the job resources using four variables referring to autonomy, learning opportunities, organizing tasks and routine tasks. Building on the previously developed JD-R model, we assume to find positive relations between the three first job resources variables and IWB. This was confirmed by various studies that found positive relations between autonomy and IWB (Krause, 2004; Ramamoorthy et al., 2005; Slåtten \& Mehmetoglu, 2011) and creativity (Unsworth, Wall, \& Carter, 2005). The role of routine tasks is more ambiguous. It can be seen as a negative indicator of job resources as employees that are obliged to perform constantly the same, short routine tasks have a narrow vision of the firm and the work procedures which inhibits them from making connections and seeing the big picture, both crucial for creative and innovative thinking (Oldham \& Cummings, 1996). Yet, some others like Ohly et al. (2006) found positive relations between routinization and employee innovation, as routine tasks enable employees to see opportunities for improvement better.

Hypothesis 1: Job resources are positively related to IWB

For job challenges, two variables are used in this research: one referring to time pressure and the other to emotional pressure. In line with previous research on the relation between job demands and IWB (e.g. Fritz \& Sonnentag, 2009; Janssen, 2000), we assume that time pressure and emotional pressure will positively relate to IWB. This is because job demands provide the need and motivation for employees to search for ways to improve and innovate on the workplace.

Hypothesis 2: Job challenges are positively related to IWB

For job hindrances we use a variable referring to job insecurity. Job insecurity was previously found to negatively affect workplace creativity as it reduces the long term engagement and commitment of the employee to the work (Sverke, Hellgren, \& Näswall, 2002). A recent research of Probst et al. (2007) combining survey and experimental research methods also showed that job insecurity is indeed related to poor creativity. According to Hartley et al. (1991), job insecurity is composed of an element referring to 'employment insecurity' (fear of losing your job), and an element referring to 'job content insecurity' (fear that your job content might change). In this research we'll focus on the second aspect of job security, the 'job content insecurity'.

Hypothesis 3: Job hindrances will be negatively related to IWB

\section{Occupational groups matter}

Not all employees are expected to react equally to the different job design variables. Groups of employees tend to differ in the way they value different aspects of a job. White collar employees are traditionally found to value more intrinsic aspects of the job while blue-collar workers attach more importance to extrinsic aspects such as 
rewards or job security (Centers \& Bugental, 1966; Locke, 1973; Mottaz, 1985; Ronen \& Sadan, 1984). Consequently, we can hypothesize that the relation between job design and employee outcomes such as IWB, is moderated by the occupational group under study. Nevertheless, only rarely articles focus on this potential moderator effect. Studies which did distinguish between occupational groups in their analyses of the effects of job characteristics on employee outcomes are the studies of Schreurs et al. (2011), Tsaur, Yen \& Yang (2010) and Toppinen-Tanner, Kalimo \& Mutanen (2002). Schreurs et al. (2011) distinguished between white- and blue-collar employees in the relation between the job design and early retirement. Tsaur, Yen \& Yang (2010) researched the job design - employee creativity relationship in the travel agency industry and distinguished between four distinct employee categories. ToppinenTanner, Kalimo \& Mutanen (2002) studied the effect of job stressors on burn-out and compared white with blue collar employee. All these studies concluded the relation between job design and employee outcomes depends on the occupational groups, but most studies only found small differences.

In order to develop hypotheses on the influence of the occupational group on the job design - IWB relation, we built further on research into workers motives. These studies generally conclude that for blue collar workers, extrinsic work aspects such as job insecurity are of central importance for their motivation, while for white collar employees intrinsic job aspects such as autonomy and work content are far more important (Centers \& Bugental, 1966; Locke, 1973; Mottaz, 1985; Ronen \& Sadan, 1984). Consequently we assume that job resources and job challenges will have larger positive relations for white-collar than for blue-collar workers. Job hindrances such as job insecurity on the other hand will have a larger negative relation with IWB for bluecollar than for white-collar employees (Sverke et al., 2002).

Hypothesis 4a: The job resources - IWB relation will be stronger for white-collar employees than for blue-collar workers.

Hypothesis $4 b$ : The job challenges - IWB relation will be stronger for white-collar employees than for blue-collar employees.

Hypothesis $4 c$ : The job hindrances - IWB relation will be stronger for blue-collar employees than for white-collar employees.

Figure 1 summarizes the hypotheses as developed based on the literature. The full line represents a hypothesized positive relation while a dashed line refers to a hypothesized negative relation between the concepts. 


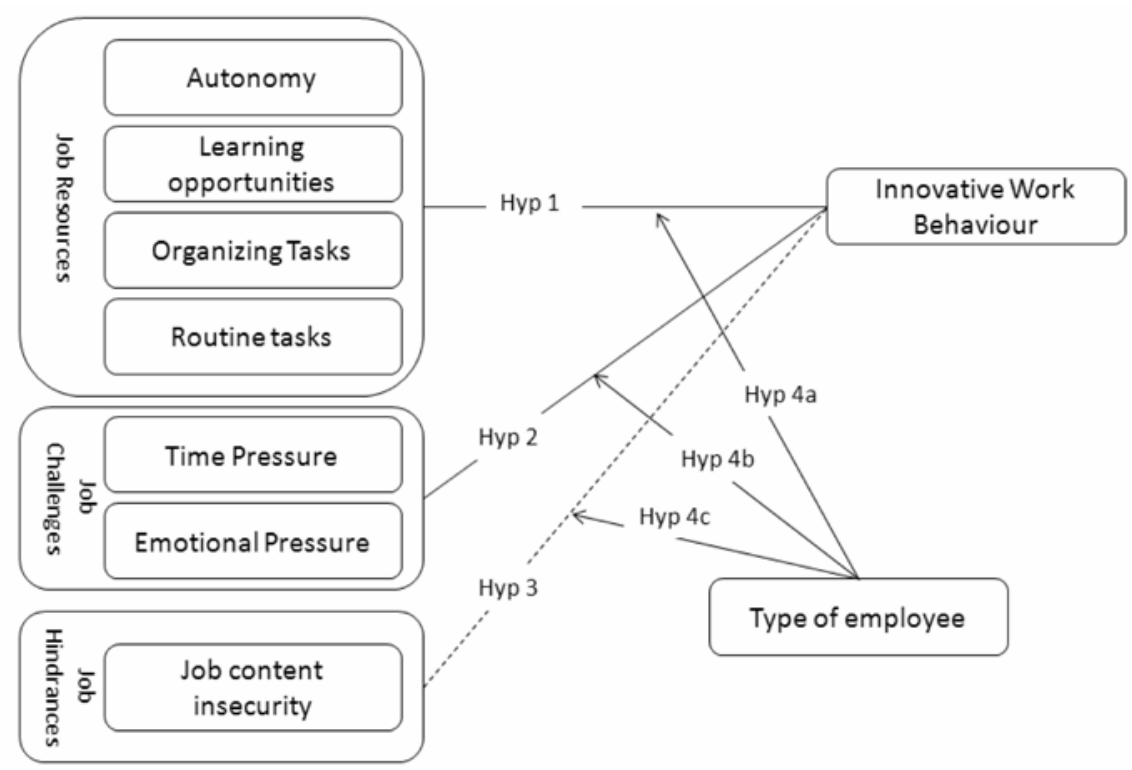

Figure 1. Hypotheses based on the literature

\section{Data \& Method}

The data to test the above mentioned hypotheses were obtained through a survey completed by 952 employees of 17 different companies from various sectors of the Flemish region in Belgium. The data were gathered in the context of a project on organizational innovation. The surveys were distributed to all employees that would participate in the upcoming project of organizational innovation. The response rate was $53 \%$, yet, 59 surveys were left out of consideration due to missing data. Of the total of 893 usable surveys, $47.89 \%$ were completed by male respondents. $60.48 \%$ of the respondents had a degree of at most higher secondary education. The average age of the respondents was 39 years old (median $40 y$ and modus 31y). Further, $41.70 \%$ of the respondents were employed as blue-collar workers and $50.05 \%$ as white-collar employees. The rest was employed as agency worker or as member of the senior management. $70.22 \%$ of the respondents were engaged as a full-time worker.

All measures were included in a paper-and-pencil survey using 5 point Likert scales ranging from 'totally agree' to 'totally disagree'. All job control, job challenges and job hindrances measures were taken from the Dutch 'Nova-Weba' survey (Schouteten \& Benders, 2004). Job control was measured using measurements of employee autonomy, organizing tasks, learning opportunities and routine tasks. The measure for autonomy included 8 items including questions like 'I can arrange my own work pace' and 'I can decide myself how I work'. Organizing tasks were measured using a scale of four items including 'I discuss how the tasks are to be planned with others'. Learning opportunities were measured using a three item scale including 'By doing my 
job, I learn new stuff' and 'I have the opportunity to develop my professional skills'. Routine tasks were measured using a three item scale including questions like 'my job is tedious'. Job challenges were measured using items referring to time pressure and emotional pressure. Time pressure was measured using a four items scale including questions like 'I have to hurry in my job' and 'I have to work under time pressure', and the three items emotional pressure scale included questions like 'My work is heavy from an emotional point of view' and 'My job puts me in emotional situations'. Further, job hindrances were measured using a single item scale referring job content insecurity: 'I feel uncertain about the future content of my job'. Innovative work behavior was measured using an adaptation of the scales used by Scott and Bruce $(1994,1998)$ Janssen $(2000,2003)$ and De Jong \& Den Hartog (2010). Respondents indicated how frequently given statements occurred in their job, ranging from 'very rarely' to 'very frequent'. Sample items are 'finding original solution for work related problems' and 'developing innovative ideas into practical applications'. The internal consistency of these scales was controlled using the Cronbach alpha, the results are given in table one and are satisfactory. Further, some control variables were included in the research: age, employment status (full time or part time employment) and company affiliation. All can have an effect on the employee innovativeness as and are therefore controlled for. As most control variables, except for age, are categorical, no beta coefficients are given in the regression analysis results.

In the first step, an exploratory factor analysis was performed on all the evaluation questions included in the survey. This factor analysis confirmed the previously defined concepts. In line with the suggestions made by Mortelmans \& Dehertogh (2008), restrictive summated scales were computed for the established factors in order to include observations with some missings but to delete observations with multiple missings on the items. The scales were in the next step centered to facilitate the plotting of the interaction effects. Correlations between the different variables are given in table one. In the second step, the correlation matrix was inspected and an ANOVA analysis was run in order to check for significant between-groups differences on the variables. In a third step, a multiple regression analysis was conducted in order to check the proposed hypotheses using the SAS enterprise guide 4.2 as supporting software. Subsequently, detected interaction effects were plotted for convenience of interpretation

\section{Results}

\section{Descriptive results}

Table 1 shows the correlation matrix of the variables used in the regression model. Inspection of the correlations between the different concepts reveals that multicollinearity is not a threat for the regression analysis. Furthermore, inspection of the variance inflations factors in the regression model indicates the same. Based on the variance inflation factors, we conclude that multicollinearity is not a problem. 
Further, inspection of the residuals of the regression model showed that the linearity and normality assumptions of the regression model are not violated.

Table 1. Correlation matrix

\begin{tabular}{lllllllllllll}
\hline & $\mathrm{Cr} \alpha$ & $\mathrm{M}$ & $\mathrm{Std}$ & 1 & 2 & 3 & 4 & 5 & 6 & 7 & 8 \\
\hline 1 & Age & - & 39.29 & 10,05 & & & & & & & & \\
2 & Autonomy & 0.84 & 5.95 & 1.81 & 0.03 & & & & & & & \\
& Organizing & 0.83 & 5.03 & 2.22 & 0.00 & $0.42^{*}$ & & & & & & \\
& Tasks & & & & & & & & & & \\
4 & Learning Opp. & 0.82 & 6.87 & 1.96 & -0.10 & $0.30^{*}$ & $0.42^{*}$ & & & & & \\
5 & Time Pressure & 0.80 & 5.70 & 1.95 & 0.02 & 0.00 & $0.11^{*}$ & $0.08 \mathrm{p}$ & & & & \\
& Emotional & & & & & & & & & & & \\
6 & Pressure & 0.88 & 4.51 & 2.47 & 0.00 & 0.03 & $0.23^{*}$ & $0.11^{*}$ & $0.32^{*}$ & & & \\
7 & Routine Tasks & 0.68 & 3.28 & 2.27 & -0.01 & $-0.24^{*}$ & $-0.31^{*}$ & $-0.34^{*}$ & $-0.13^{*}$ & $-0.13^{*}$ & & \\
8 & Job Insecurity & - & 4.30 & 2.14 & -0.06 & $-0.13^{*}$ & $-0.14^{*}$ & $-0.13^{*}$ & $0.14^{*}$ & $0.09 \mathrm{p}$ & $0.09 \mathrm{p}$ & \\
9 & IWB & 0.96 & 4.80 & 1.61 & -0.06 & $0.27^{*}$ & $0.46^{*}$ & $0.46^{*}$ & $0.14^{*}$ & $0.21^{*}$ & $-0.24^{*}$ & -0.08 \\
\hline
\end{tabular}

${ }^{*}$ significant at the $<.001$ level, $p$ significant at the 0.05 level

Further, we inspect the mean differences between the two groups of employees: blue- and white-collar employees. In Table 2, the results of an ANOVA are shown. Clearly blue- and white-collar employees differ significantly regarding their job characteristics and their behavior. White-collar employees have higher levels of all job characteristics that we hypothesized to be positively related to IWB. Blue-collar workers on the other hand have higher levels of what we defined as a 'job hindrance': job content insecurity. Consequently, in terms of IWB, white-collars have significantly higher levels then blue-collar workers. Nevertheless, using regression analysis we will focus not on the mean differences between the groups, but on the differences in the explanatory value of the job characteristics variables.

Table 2. ANOVA analysis

\begin{tabular}{|c|c|c|c|c|c|c|}
\hline & Blue Worker & Collar & & ite Collar & ker & \\
\hline & mean & sd. & mean & sd. & F-value & \\
\hline Autonomy & 5.22 & 1.80 & 6.50 & 1.61 & $120.82^{*}$ & white $>$ blue \\
\hline $\begin{array}{l}\text { Organizing } \\
\text { Tasks }\end{array}$ & 3.98 & 2.18 & 5.84 & 1.90 & 178.99* & white $>$ blue \\
\hline $\begin{array}{l}\text { Learning } \\
\text { Opp. }\end{array}$ & 6.34 & 1.94 & 7.24 & 1.84 & $48.00^{*}$ & white $>$ blue \\
\hline $\begin{array}{l}\text { Time } \\
\text { Pressure }\end{array}$ & 5.44 & 1.90 & 5.91 & 1.95 & $12.17^{*}$ & white $>$ blue \\
\hline $\begin{array}{l}\text { Emotional } \\
\text { Pressure }\end{array}$ & 3.59 & 2.21 & 5.24 & 2.43 & $105.64^{*}$ & white $>$ blue \\
\hline $\begin{array}{l}\text { Routine } \\
\text { Tasks }\end{array}$ & 4.36 & 2.14 & 2.44 & 2.01 & $181.40^{*}$ & blue $>$ white \\
\hline $\begin{array}{l}\text { Job Content } \\
\text { Insec. }\end{array}$ & 2.89 & 1.01 & 2.59 & 1.07 & $18.04^{*}$ & blue $>$ white \\
\hline IWB & 4.41 & 1.52 & 5.09 & 1.61 & $39.12^{*}$ & white $>$ blue \\
\hline
\end{tabular}




\section{Regression Results}

To test the established hypotheses a three step regression analysis was run. In the first step, only control variables referring to the age of the employee, the company, the status of the employee as a blue- or white-collar employee and his working time arrangement were included. In the second step, job design variables referring to job resources (autonomy, organizing tasks, learning opportunities and routine tasks), job challenges (time pressure and emotional pressure) and job hindrances (job content insecurity) were included in the analysis. In the third and last step, interaction effects of the employee status with the different job design variables were included in the analysis. Results are shown in Table 3.

Table 3. Regression analysis

\begin{tabular}{|c|c|c|c|c|c|c|}
\hline & \multicolumn{6}{|c|}{ Innovative Work Behaviour } \\
\hline & \multicolumn{2}{|c|}{ Step 1} & \multicolumn{2}{|c|}{ Step 2} & \multicolumn{2}{|c|}{ Step 3} \\
\hline & Beta & Sign & Beta & Sign & Beta & Sign \\
\hline \multicolumn{7}{|l|}{ Control } \\
\hline Blue Collar - White Collar & - & $<.001$ & - & 0.099 & - & 0.127 \\
\hline Age & -0.008 & 0.147 & -0.006 & 0.241 & -0.006 & 0.203 \\
\hline Fulltime $(0 / 1)$ & - & 0.015 & - & 0.072 & - & 0.079 \\
\hline Company & - & $<.001$ & - & $<.0001$ & - & $<.0001$ \\
\hline \multicolumn{7}{|l|}{ Job resources - challenges - hindrances } \\
\hline Autonomy & & & 0.065 & 0.036 & 0.034 & 0.009 \\
\hline Organizing Tasks & & & 0.198 & $<.0001$ & 0.262 & $<.0001$ \\
\hline Learning Opportunities & & & 0.260 & $<.0001$ & 0.290 & $<.0001$ \\
\hline Time Pressure & & & 0.016 & 0.574 & -0.011 & 0.490 \\
\hline Emotional Pressure & & & 0.038 & 0.088 & 0.014 & 0.117 \\
\hline Routine Tasks & & & -0.056 & 0.025 & -0.093 & 0.056 \\
\hline Job Content Insecurity & & & -0.003 & 0.941 & 0.069 & 0.741 \\
\hline \multicolumn{7}{|l|}{ Interactions } \\
\hline Autonomy*blue collar worker & & & & & 0.097 & 0.121 \\
\hline Autonomy*white collar worker & & & & & - & - \\
\hline Organizing Tasks*blue collar worker & & & & & -0.145 & 0.007 \\
\hline Organizing Tasks*white collar worker & & & & & - & - \\
\hline Learning Opp.*blue collar worker & & & & & -0.077 & 0.187 \\
\hline Learning Opp.* white collar worker & & & & & - & - \\
\hline Time Pressure*blue collar worker & & & & & 0.063 & 0.288 \\
\hline Time Pressure*white collar worker & & & & & - & - \\
\hline Emotional Pressure*blue collar worker & & & & & 0.047 & 0.327 \\
\hline Emotional Pressure*white collar worker & & & & & - & - \\
\hline Routine Tasks*blue collar worker & & & & & 0.090 & 0.072 \\
\hline Routine Tasks*white collar worker & & & & & - & - \\
\hline Job Content Insec.*blue collar worker & & & & & -0.170 & 0.081 \\
\hline Job Content Insec.* white collar worker & & & & & - & - \\
\hline R square & 0.116 & 0.360 & 0.378 & & & \\
\hline
\end{tabular}


Using these regression results we control the various proposed hypotheses. The first hypothesis is fully confirmed as we found strong positive relations between three job resources variables (autonomy, organizing tasks \& learning opportunities) and IWB. Moreover, these relations are particularly strong. The found beta coefficients are the highest for learning opportunities and organizing tasks, both in the second as in the third model. The relation between routine tasks and IWB was found to be significantly negative in model, suggesting that routine tasks are indeed a negative indicator for job resources which inhibits the innovative potential of employees. Hypothesis two on the other hand is only partly confirmed. Job challenges seem to relate positively with IWB, but the relation is very weak and insignificant in the second model. Hypothesis three is, based on the second model, rejected as we could not find a significant relation between job content insecurity and IWB.

Having analyzed the direct effects between the job design variables and IWB, we now turn to the analysis of hypothesis 4 , regarding the interaction effect of the type of employee on the relation between job design and IWB. We found significant differences in the relation between job design and IWB for blue- and white-collar workers for the following variables: organizing tasks, routine tasks and job content insecurity. We thus conclude that hypothesis $4 a$ is partly confirmed as we found two job resource variables to interact with the type of employee. Hypothesis $4 \mathrm{~b}$ is fully rejected; the relation between job challenges such as time pressure and emotional pressure does not significantly differ according the status of the employee. Hypothesis $4 \mathrm{c}$ on the other hand is fully confirmed. The relation between job content insecurity and IWB is significantly different for blue-collar workers than for white-collar workers. For the convenience of interpretation, we plotted the various interaction effects using the guidelines of Aiken and West (1991) and Panik (2009) as can be seen in Figure 2, 3 and 4.

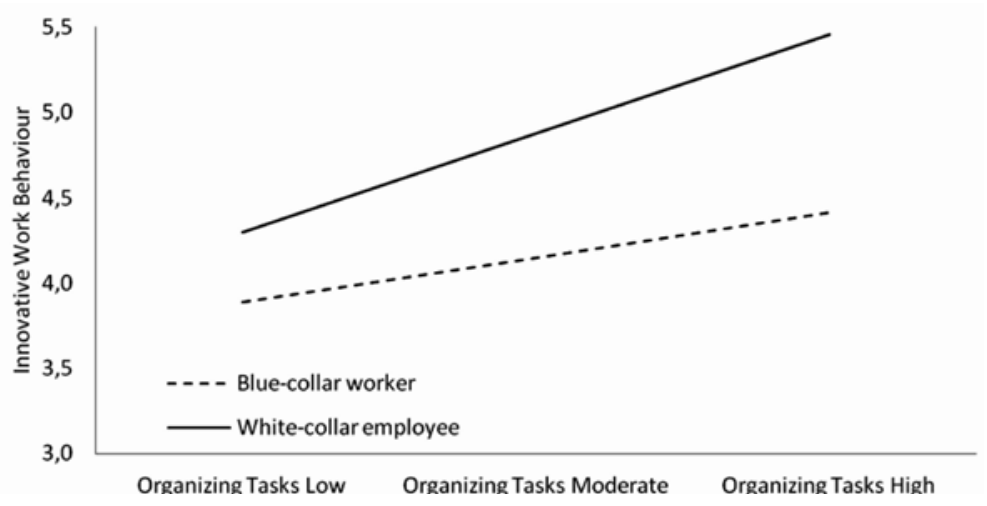

Figure 2. Interaction Organizing Tasks*Employee status on IWB

Figure 2 shows the interaction between organizing tasks and employee status on IWB. The positive relation between organizing tasks and IWB is amplified for white 
collar employees in comparison with blue-collar employees. Figure 3 on the interaction between routine tasks and employee status on IWB shows the inverse effect. Here, there is no clear relation between routine tasks and IWB for blue collar employees, yet for white collar employees the relation is significantly negative.

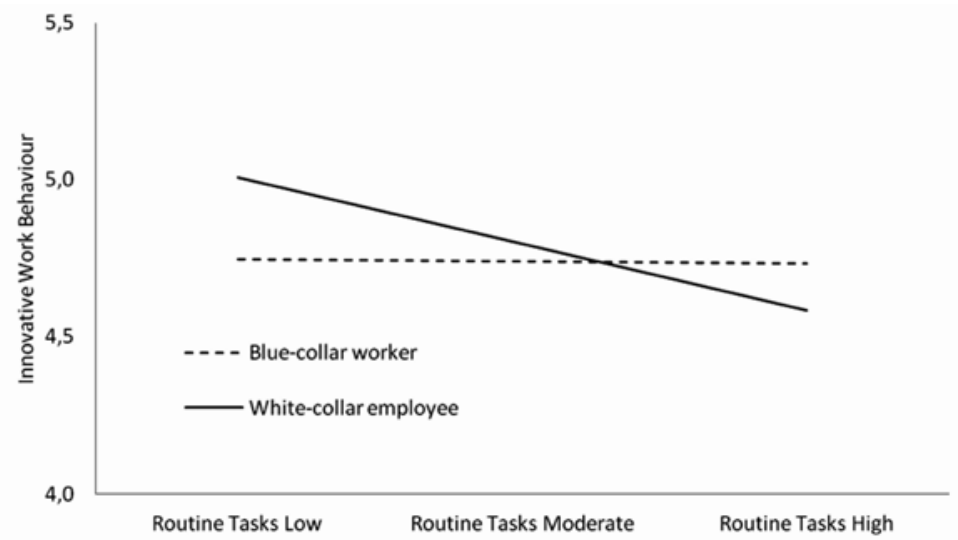

Figure 3. Interaction Routine Tasks*Employee status on IWB

Figure 4 finally shows the interaction between job security and employee status on IWB. The non-significant relation between job content insecurity and IWB in step two of our regression analysis can be explained by the pattern of Figure 4. Here, we obviously see that job content insecurity has a strong negative relation with IWB for blue-collar workers, yet a weaker but positive relation for white-collar workers.

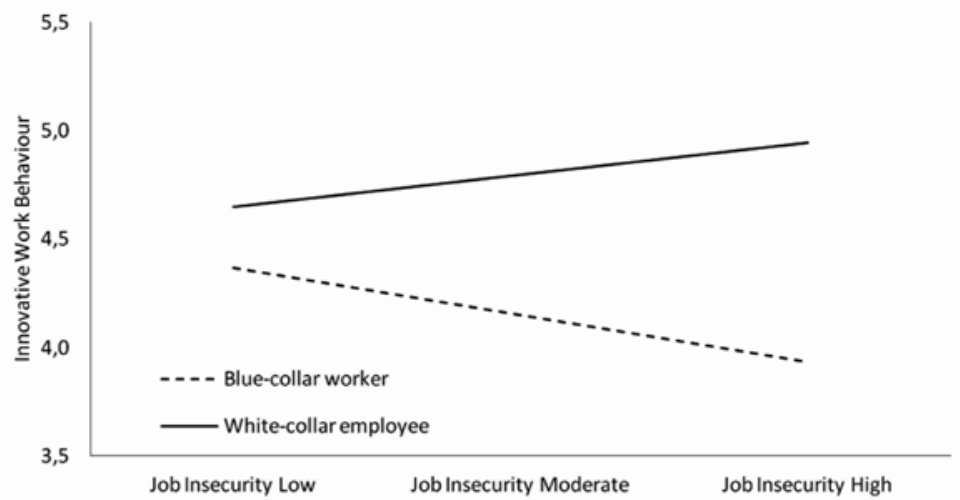

Figure 4. Interaction Job Insecurity*Employee status on IWB 


\section{Limitations}

The study faces nevertheless some limitations. First, all data come from a single source, using a single method. Although various authors suggest that this does not significantly bias the results (Spector, 2006), others state that this leads to a 'common method bias' which can inflate the associations between the concepts. Finding interaction effects in the data nevertheless decreases the odds of a serious bias due to common method variance (Siemsen, Roth, \& Oliveira, 2010). A second limitation is the cross-sectional design of the study. Therefore, no causal relations can be established. Alternative explanations can refer to the employee personality or the effect of innovative behavior on the job through job crafting (Berg, Dutton, \& Wrzesniewski, 2008) of employees.

\section{Conclusion \& Discussion}

This article contributed to the debate on how organizations can become flexible, learning type organizations based on the innovative engagement of their employees. In doing so, we used the Job Demands-Resources model of Bakker \& Demerouti (2007) as a starting point, and applied recent insights on the differential nature of job demands (Van den Broeck et al., 2010). The results of the analysis of the relation of job challenges and job hindrances with IWB were in line with the idea that job challenges are job demands that can have positive employee outcomes whereas job hindrances have uniquely negative relations with employee outcomes. Further, the study stressed the importance of distinguishing between different employee categories when focusing on the impact of job design variables. The article used traditional insights on work motivations of blue- and white-collar workers and applied them to the relation between job design and IWB.

The findings in this article show that the relation between the job design and IWB differs significantly for blue- and white-collar employees. Job resources, such as organizing tasks, have a more positive relation with IWB for white-collar workers in comparison with blue-collar workers. Routine tasks on the other hand were found to have a significant negative effect for white collar workers, while this is not the case for blue-collar workers. This finding can be linked to previous literature which identified routine tasks both as a potential obstacle and a driver for innovative behavior. Regarding job hindrances, the found relation between job content insecurity and IWB was positive for white-collar employees, yet rather strongly negative for bluecollar employees. Further, regarding the relation between job challenges such as time pressure and emotional pressure, no significant differences were found between employee categories.

Although the study faces limitations, the findings can nevertheless be translated into the HRM practice. First, the findings suggest that HR managers wishing to unlock the innovative potential of employees should focus on the job design as it is a crucial predictor for IWB. In doing so, HR managers can focus on increasing the job resources, decreasing the job hindrances or evaluating the role of job challenges, yet the findings indicate that the strongest relations are found between job resources 
and IWB. Increasing the organizing tasks of employees and their opportunities to use and develop their professional skills has the strongest relation with employee innovativeness. This is in line with the insights of Lorenz \& Valeyre (2005) who differentiated between 'lean organizations' and 'learning organizations'. In both, employees had high levels of autonomy, yet this is combined in the lean organization with monotonous and repetitive jobs which, according to our findings, serve as an obstacle to employee innovativeness for white-collar workers. Second, HR managers should adapt and change their interventions depending on the population in focus. Although job resources are an essential driver of IWB for all employees, the relation is even stronger for white-collar employees. Low resources jobs with a lot of short routine are absolutely to be avoided if HR managers seek to stimulate the innovativeness of white-collar workers. Regarding job content insecurity, it seems that, at least on the individual level and for blue-collar employees, the ever-increasing pressure towards more flexibility might have negative side-effects on the innovative behavior of the employees, and therefore maybe the innovative potential of the organizations at large. As such, it seems that flexibilisation and innovation are not always compatible strategies for organizations.

\section{References}

Aiken, L. S., \& West, S. G. (1991). Multiple Regression: Testing and Interpreting Interactions. London: Sage Publications.

Baer, M., Oldham, G. R., \& Cummings, A. (2003). Rewarding creativity: when does it really matter? The Leadership Quarterly, 14(4-5), 569-586.

Bakker, A. B., \& Demerouti, E. (2007). The job demands-resources model: State of the art. Journal of Managerial Psychology, 22(3), 309-328.

Bakker, A. B., van Veldhoven, M., \& Xanthopoulou, D. (2010). Beyond the DemandControl Model. Journal of Personnel Psychology, 9(1), 3-16. doi:10.1027/1866-5888/ a000006.

Beer, M., Spector, B., Lawrence, P. R., Quinn Mills, D., \& Walton, R. E. (1984). Managing Human Assets (illustrated ed.). Macmillan USA.

Berg, J. M., Dutton, J. E., \& Wrzesniewski, A. (2008). What is Job Crafting and Why Does It Matter?

Briner, R. B., \& Rousseau, D. M. (2011). Evidence-Based I-O Psychology: Not There Yet. Industrial and Organizational Psychology, 4(1), 3-22. doi:10.1111/j.17549434.2010.01287.x.

Centers, R., \& Bugental, D. (1966). Intrinsic and Extrinsic Job Motivations among different segments of the working population. Journal of Applied Psychology, 50(3), 193-197.

Darroch, J. (2005). Knowledge management, innovation and firm performance. Journal of Knowledge Management, 9(3), 101-115. doi:10.1108/13673270510602809.

de Jong, J., \& Den Hartog, D. (2010). Measuring Innovative Work Behaviour. Creativity and Innovation Management, 19(1), 23-36. 
De Spiegelaere, S. (2011). Innovative Work Behaviour: Concept and Measurement. Presented at the EDI Conference, Bologna.

Dewett, T. (2004). Employee creativity and the role of risk. European Journal of Innovation Management, 7(4), 257-266.

Fritz, C., \& Sonnentag, S. (2009). Antecedents of Day-Level Proactive Behavior: A Look at Job Stressors and Positive Affect During the Workday†. Journal of Management, 35(1), 94 -111. doi:10.1177/0149206307308911.

Getz, I., \& Robinson, A. G. (2003). Innovate or Die: Is that a Fact? Creativity and Innovation Management, 12(3), 130-136. doi:10.1111/1467-8691.00276.

Hammond, M. M., Neff, N. L., Farr, J. L., Schwall, A. R., \& Zhao, X. (2011). Predictors of individual-level innovation at work: A meta-analysis. Psychology of Aesthetics, Creativity, and the Arts, 5(1), 90-105. doi:10.1037/a0018556.

Hartley, J. (1991). Job insecurity: coping with jobs at risk. Sage Publications.

Holman, D., Totterdell, P., Axtell, C., Stride, C., Port, R., Svensson, R., \& Zibarras, L. (2011). Job Design and the Employee Innovation Process: The Mediating Role of Learning Strategies. Journal of Business and Psychology. doi:10.1007/s10869-011-9242-5.

Janssen, O. (2000). Job demands, perceptions of effort-reward fairness and innovative work behaviour. Journal of Occupational and Organizational Psychology, 73, 287302.

Janssen, O. (2003). Innovative behaviour and job involvement at the price of conflict and less satisfactory relations with co-workers. Journal of Occupational and Organizational Psychology, 76, 347-364.

Karasek, R., \& Theorell, T. (1990). Healthy Work. Stress, Productivity, and the Reconstruction of Working Life. New York: Basic Books.

Locke, E. A. (1973). Satisfiers and dissatisfiers among white-collar and blue-collar employees. Journal of Applied Psychology, 58(1), 67-76.

Lorenz, E., \& Valeyre, A. (2005). Organisational Innovation, Human Resource Management and Labour Market Structure: A Comparison of the EU-15. Journal of Industrial Relations, 47(4), 424-442.

Martín, P., Salanova, M., \& Maria Peiro, J. (2007). Job demands, job resources and individual innovation at work: Going beyond Karasek' s model? Psicothema, 19(4), 621-626.

Mortelmans, D., \& Dehertogh, B. (2008). Factoranalyse. Stap in Statistiek en Onderzoek. Leuven: Acco.

Mottaz, C. J. (1985). The Relative Importance of Intrinsic and Extrinsic Rewards as Determinants of Work Satisfaction. The Sociological Quarterly, 26(3), 365-385.

Ohly, S., Sonnentag, S., \& Pluntke, F. (2006). Routinization, work characteristics and their relationships with creative and proactive behaviors. Journal of Organizational Behavior, 27(3), 257-279. doi:10.1002/job.376.

Oldham, G. R., \& Cummings, A. (1996). Employee Creativity: Personal and Contextual Factors at Work. Academy of Management Journal, 39(3), 607-634. 
Panik, M. (2009). Regression Modeling: Methods, Theory, and Computation with SAS. Chapman and Hall/CRC.

Podsakoff, N. P., LePine, J. A., \& LePine, M. A. (2007). Differential challenge stressorhindrance stressor relationships with job attitudes, turnover intentions, turnover, and withdrawal behavior: A meta-analysis. Journal of Applied Psychology, 92(2), 438-454. doi:10.1037/0021-9010.92.2.438.

Polanyi, M. (1966). The Tacit Dimension. New York: Anchor Day Books.

Probst, T. M., Stewart, S. M., Gruys, M. L., \& Tierney, B. W. (2007). Productivity, counterproductivity and creativity: The ups and downs of job insecurity. Journal of Occupational and Organizational Psychology, 80(3), 479-497.

Ronen, S., \& Sadan, S. (1984). Job Attitudes Among Different Occupational Status Groups. Work and Occupations, 11(1), 77-97.

Schouteten, R., \& Benders, J. (2004). Lean Production Assessed by Karasek's Job Demand-Job Control Model. Economic and Industrial Democracy, 25(3), 347 -373. doi:10.1177/0143831X04044831.

Schreurs, B., Van Emmerik, H., De Cuyper, N., Notelaers, G., \& De Witte, H. (2011). Job demands-resources and early retirement intention: Differences between blue-and white-collar workers. Economic and Industrial Democracy, 32(1), 47-68. doi:10.1177/0143831X10365931.

Scott, S. G., \& Bruce, R. A. (1994). Determinants of innovative behavior: A path model of individual innovation in the workplace. Academy of Management Journal, 37(3), 580-607.

Scott, S. G., \& Bruce, R. A. (1998). Following the leader in R\&D: the joint effect of subordinate problem-solving style and leader-member relations on innovative behavior. Engineering Management, IEEE Transactions on, 45(1), 3-10. doi:10.1109/17.658656.

Siemsen, E., Roth, A., \& Oliveira, P. (2010). Common Method Bias in Regression Models With Linear, Quadratic, and Interaction Effects. Organizational Research Methods, 13(3), 456 -476. doi:10.1177/1094428109351241.

Spector, P. E. (2006). Method Variance in Organizational Research. Organizational Research Methods, 9(2), 221-232. doi:10.1177/1094428105284955.

Sverke, M., Hellgren, J., \& Näswall, K. (2002). No security: A meta-analysis and review of job insecurity and its consequences. Journal of Occupational Health Psychology, 7(3), 242-264. doi:10.1037/1076-8998.7.3.242.

Toppinen-Tanner, S., Kalimo, R., \& Mutanen, P. (2002). The process of burnout in whitecollar and blue-collar jobs: eight-year prospective study of exhaustion. Journal of Organizational Behavior, 23(5), 555-570. doi:10.1002/job.155

Tsaur, S.-H., Yen, C.-H., \& Yang, W.-Y. (2010). Do job characteristics lead to employee creativity in travel agencies? International Journal of Tourism Research, n/a-n/a. doi:10.1002/jtr.809.

Unsworth, K., Wall, T. D., \& Carter, A. (2005). Creative Requirement. Group \& Organization Management, 30(5), 541 -560. doi:10.1177/1059601104267607. 
Van den Broeck, A., De Cuyper, N., De Witte, H., \& Vansteenkiste, M. (2010). Not all job demands are equal: Differentiating job hindrances and job challenges in the Job Demands-Resources model. European Journal of Work and Organizational Psychology, 19(6), 735-759. doi:10.1080/13594320903223839.

\section{Abstract (in Polish)}

W sytuacji, gdy innowacyjni pracownicy staja się niezbędnym elementem sukcesu firmy, badania identyfikuja projekt stanowiska pracy jako kluczowq zmiennq w promowaniu innowacyjnego zachowania w pracy (Hammond et al., 2011). Stosujqc Model JD-R Bakkera i Demerouti'ego (2007), artykuł ten wnosi nowe spojrzenie na rozróżnienie między wyzwaniami i przeszkodami w pracy (Van den Broeck et al., 2010) i analizuje je dla pracowników umysłowych i fizycznych. Wykorzystujqc dane pochodzqce od 893 pracowników rozmaitych organizacji, wyniki generalnie potwierdzajq słusznośćmodeluJD-R, natomiastzauważono poważneróżnice międzypracownikami umysłowymi i fizycznymi dotyczqce organizowania oraz rutynowych zadań w innowacyjnym zachowaniu w pracy. Niepewność co do treści stanowiska pracy wywiera negatywny wpływ na innowacyjne zachowanie pracowników fizycznych. Wyniki badań majq ważne implikacje polityczne jak i w zakresie ZZL, ponieważ dowodzq, że nie istnieje jedno standardowe rozwiqzanie ZZL w zakresie innowacji.

Stowa kluczowe: innowacyjne zachowanie w pracy (IWB), Projekt stanowiska pracy, ZZL, pracownicy umysłowi, pracownicy fizyczni. 